13. Цебржинский О. И. Количественное определение супероксида НСТ-тестом в тканях / О. И. Цебржинский // Організація токсикологічної допомоги в Україні : тези доп. наук.-практ. конф. - К., 2002. С. $65-66$.

14. Цебржинский О. И. Некоторые аспекты антиоксидантного статуса / О. И. Цебржинский // Физиология и патология перекисного окисления липидов, гемостаза и иммуногенеза. - Полтава, 1992. - С. 120-155.

15. Antioxidant and antiapoptotic properties of melatonin restore intestinal calcium absorption altered by menadione / [A. Carpentieri, A. Marchionatti, V. Areco et al.] // Molecular and Cellular Biochemistry. - 2014. V. 387. - Issue 1. - P. 197-205.

16. Bubenik G. A. Localization of melatonin in the digestive tract of the rat: effect of maturation, diurnal variation, melatonin treatment and pinealectomy / G. A. Bubenik // Horm. Res. - 1980. - V. 12. - P. $313-323$.

17. Reiter R. J. Melatonin: Lowering the High Price of Free Radicals / R. J. Reiter // News Physiol. Sci. - 2000. Vol. 15. - P. 246-250.

Анасевич Ярослав. Влияние избытка и недостатка мелатонина на продукцию супероксида в тонкой кишке крыс. В тонкой кишке крыс недостаток мелатонина на протяжении 30 суток (круглосуточное освещение 1000-1500 лк) способствует увеличению продукции супероксиданионрадикала от фагоцитарных электороннотранспортных цепей, а избыток мелатонина (содержание крыс в темноте и пероральное введение мелатонина в ежедневной дозе 1 мг/кг массы тела) - от митохондриального окисления, что отвечает антиоксидантным способностям мелатонина. Вытек супероксида с микросомальной электронно-транспортной цепи окисления в обоих случаях не изменялся. При сравнении одинаковых по сроку действия недостатка и избытка мелатонина оказалось, что при недостатке относительная масса тонкой кишки в 1,8 раза меньше, чем при избытке. Почти в два раза относительная масса тонкой кишки при 30-дневном недостатке мелатонина меньше условной нормы. На 10 \% коэффициент массы тонкой кишки при избытке мелатонина меньше условной нормы, можно оценить как следствие дисбаланса продукции мелатонина.

Ключевые слова: тонкий кишечник, супероксиданионрадикал, гипомелатонинемия, гипермелатонинемия.

Anasevych Jaroslav. Effect of Excess and Shortage of Melatonin on Superoxide Production in the Small Intestine of Rats. In the small intestine of rats lack of melatonin for 30 days (lighting 1000-1500 lux) increases production by phagocytic elektoronno superoksidanionradikal transport chains, and the excess of melatonin (the content of rats in the dark, and oral administration of melatonin in a daily dose of $1 \mathrm{mg} / \mathrm{kg}$ body weight) - from mitochondrial oxidation, which corresponds to the antioxidant capacity of melatonin. Emerging superoxide with microsomal electron transport chain oxidation in both cases did not change. When comparing the same for the term of the shortage and excess of melatonin it was found that the shortage of the relative weight of the small intestine is 1,8 times less than the excess. Almost twice the relative weight of the small intestine in a 30-day conditional lack of melatonin is less than normal. $10 \%$ weight ratio of the small intestine with an excess of melatonin less conventional standards, can be estimated as a result of an imbalance of melatonin production.

Key words: small intestine, superoxidanionradical, hipomelatoninnemia, hypermelatoninnemia.

Стаття надійшла до редколегії 28.09.2015 p.

УДК 613.84-055.2

\author{
Людмила Апончук, \\ Тетяна Шевчук, \\ Ніна Бернацька
}

\title{
Аналіз показників розумової та фізичної працездатності в жінок-курців
}

Проаналізовано та вивчено особливості стану показників розумової й фізичної працездатності в жіноккурців. Установлено, що в них рівень фізичної працездатності за визначенням індексу гарвардського стептесту відповідає слабкому (I група) та середньому (II група), що вказує на низький рівень функціонального стану серцево-судинної системи обстежуваних осіб. Дослідження розумової працездатності засвідчило, що в жінок-курців I й II груп показник розумової працездатності відповідає низькому рівню за шкалою оцінювання,

(С) Апончук Л., Шевчук Т., Бернацькка Н., 2015 
що пояснюється згубною дією тривалого куріння на нервову систему, поступове зниження уваги, пам'яті, працездатності, ефективності засвоєння нових знань.

Ключові слова: тютюнопаління, жінки, фізична працездатність, розумова працездатність.

Постановка наукової проблеми та ії значення. Сучасна молодь, особливо на початковому етапі навчання, стикається 3 низкою труднощів, пов'язаних зі збільшенням навчального навантаження, малою руховою активністю, відносною свободою студентського життя, проблемами в соціальному та міжособистісному спілкуванні. Загрозливо зростає великий контингент тих, хто вважає, що можна зняти стрес, утому за допомогою куріння (до $19 \%$ ), алкоголю (12\%) [4].

Нині куріння перетворилось у масову «епідемію», яка завдає значної шкоди здоров'ю. Тютюнопаління - причина багатьох захворювань, воно різко скорочує тривалість життя, знижує працездатність, згубно відбивається на здоров’ї підростаючого покоління [1].

Фахівці з'ясували, що через 5-9 хвилин після викурювання лише однієї сигарети сила м'язів знижується на $15 \%$. Крім того, куріння погіршує розумову діяльність (знижується точність сприйняття інформації) [7], а також фізичну працездатність.

Розумова праця пов'язана з прийомом і переробкою інформації та потребує переважно напруження вищої нервової (психічної) діяльності (ВНД). Головними характеристиками ВНД при розумовій праці є психофізіологічні якості й психічні пізнавальні процеси. До професійно важливих психічних пізнавальних процесів розумової праці відносять сприймання, пам'ять, увагу, мислення та емоції.

Думка про те, що паління начебто підвищує працездатність, покращує розумову діяльність, не має підгрунтя і $є$ помилковою. Нікотин лише спочатку збуджує клітини головного мозку й короткочасно розширює його судини. У подальшому вони звужуються, погіршується кровообіг, знижується працездатність, настає упадок сил, з'являється головний біль, погіршується пам'ять [13]. Отже, для оцінки розумової праці потрібно дослідити психічні пізнавальні процеси та психофізіологічні якості, а для оцінки всіх побічних показників - ще й фізичну працездатність.

Рухова активність сучасної молоді сьогодні зменшується у всіх вікових діапазонах [2], що засвідчує аналіз достатньо великого матеріалу вітчизняних $\mathrm{i}$ зарубіжних джерел. Науковець відзначає, що до 21 року життя лише $40 \%$ чоловіків та $30 \%$ жінок мають необхідний рівень рухової активності, який забезпечує достатній рівень розумової й фізичної працездатності.

Студентство - особлива соціальна група, для якої характерне зниження рухової активності внаслідок збільшення витрат часу на навчальну діяльність, що, зі свого боку, негативно позначається на стані здоров'я студентів. При цьому негативний вплив гіподинамії значно посилюється через різні шкідливі звички (куріння, уживання тонізуючих та алкогольних напоїв), які призводять до раннього зношування молодого організму [11, с. 9].

Однак до сьогодні, незважаючи на велике теоретичне й практичне значення цих досліджень, зазначена проблема залишається недостатньо вивченою. Майже відсутні праці, де б указувався взаємозв' язок тютюнопаління й розумової та фізичної працездатності. Тому, виходячи з вищесказаного, це дослідження $є$ актуальним.

Мета статті - вивчити особливості стану показників розумової й фізичної працездатності в жінок-курців.

Методика та контингент дослідження. Дослідження проводили в лабораторії «Екологічної фізіології» кафедри фізіології людини і тварин біологічного факультету Східноєвропейського університету імені Лесі Українки.

Фізичну працездатність вивчали за методикою гарвардського степ-тесту. Сутність його полягає в підйомах на сходинку висотою 43 см для жінок упродовж 5 хв у заданому темпі. Темп руху постійний і дорівнює 30 циклам за хвилину, кожен із яких складається 3 чотирьох кроків. Темп задається метрономом або за командою дослідника - 120 ударів за хвилину. За командою «раз» обстежуваний ставить ногу на сходинку, «два» - стає на неї двома ногами й випрямляється, «три»опускає на підлогу ту ногу, із якої починав хід, «чотири» - стає на підлогу двома ногами та приймає вертикальне положення. Хід рекомендується починати з тієї самої ноги. За 5 хвилин можна кілька разів змінювати ногу. Якщо обстежуваний втомлюється та відстає від ритму на 20 секунд, дослідження припиняється й фіксується час виконаної роботи. Після завершення тесту обстежуваний 
сідає на стілець і на першій половині другої хвилини $\left(\mathrm{a}_{2}\right)$, на першій половині третьої хвилини $\left(\mathrm{a}_{3}\right)$ та на першій половині четвертої хвилини $\left(\mathrm{a}_{4}\right)$ за 30 секунд підраховує свій пульс.

Фізичну працездатність, або індекс гарвардського степ-тесту (ІГСТ), обчислюють за формулою:

$$
\text { IГСТ }=((\text { час підйому в секундах }) \times 100) /\left(\left(\mathrm{a}_{2}+\mathrm{a}_{3}+\mathrm{a}_{4}\right) \times 2\right) .
$$

Розумову працездатність досліджували за методикою коректурних проб (кілець Ландольта), на комплексі програмних й апаратних методів медичного обстеження дітей та дорослих «Аскольд» (Київ, 1998). Ця методика полягає у відшукуванні й закреслюванні досліджуваним кілець із заданим напрямом розриву. Для експерименту досліджуваному подається таблиця 3 кільцями Ландольта $32 \times 32$. Експериментатор робить вибір направлення розриву та надає досліджуваному місце за дисплеєм (переміщення маркера здійснюється за допомогою клавіш $\leftarrow, \rightarrow, \uparrow, \downarrow$, а для вибору використовують клавішу «ENTER»). Після ознайомлення 3 інструкцією на екрані з'являється таблиця із кілець, фрагмент якої досліджуваний може бачити у верхньому лівому куті. Після появи таблиці потрібно розпочати перегляд кожного рядка таблиці зліва направо, зверху вниз, як зазвичай під час читання. Усі кільця із заданим розривом потрібно закреслювати за допомогою клавіші «ПРОБІЛ». Повторне натиснення клавіші скасовує вибір. Після кожної хвилини перегляду на екрані в поточній позиції з'являється вертикальна риска, повернутися за неї не можна. Зразок кілець, який потрібно закреслювати, зображено зліва. Дослідження триває 5 хв. Після закінчення цього часу в поточній позиції з'являється подвійна вертикальна риска. Працювати потрібно якомога швидше й водночас намагатися не пропустити жодного кільця із заданим напрямком розриву. Після завершення часу тестування результати обробляють автоматично та виводять у вигляді таблиці на монітор комп'ютера.

Для обчислення показника розумової працездатності (Р) застосовують формулу:

$$
\mathrm{P}=\mathrm{A} * \mathrm{~S}
$$

де $A$ - коефіцієнт точності виконання ( $A=\frac{M}{N}$, де $M$ - кількість закреслених кілець;

$N$ - загальна чисельність кілець, які потрібно закреслити в переглянутому тексті);

$S$ - загальна кількість переглянутих знаків.

У ході дослідження обстежено 120 осіб жіночої статі віком 17-21 років. Їх поділено на три групи (за тестом Фагерстрема):

- I група - жінки, які мають стаж куріння понад три роки, за добу викурюють понад 10 сигарет і мають високий рівень залежності (40 осіб);

- II група - жінки зі стажем куріння 1-3 роки, котрі за добу викурюють до 10 сигарет і мають низький та середній рівні залежності (40 осіб);

- III група - жінки, які не курять (40 осіб) [12].

Для аналізу результатів дослідження використано методи параметричної й непараметричної статистики (залежно від розподілу значень). Статистичну обробку даних здійснювали за допомогою програмного забезпечення MedStat, нормальність розподілів змінних перевіряли тестом ШапіроВілка, для визначення доступності значень використовували критерій Стьюдента [10].

Виклад основного матеріалу й обгрунтування отриманих результатів дослідження. При виконанні гарвардського степ-тесту рівень фізичної працездатності виявив такі закономірності.

Після завершення тесту на першій половині другої хвилини частота серцевих скорочень (ЧСС) у I групі досліджуваних коливалась у межах від 83 до 184 уд./хв. На першій половині третьої хвилини ЧСС перебувала в межах від 70 до 144 уд./хв, на першій половині четвертої хвилини виконання фізичного навантаження - від 70 до 128 уд./хв.

У ІІ групі досліджуваних на першій половині другої хвилини ЧСС коливалась у межах від 56 до 152 уд./хв, на першій половині третьої хвилини - 71-132 уд./хв, а на першій половині четвертої хвилини - 68-120 уд./хв.

У ІІІ групі досліджуваних жінок ЧСС на першій половині другої хвилини коливалась у межах від 54 до 132 уд./хв, для першої половини третьої хвилини - 63-110 уд./хв, а на першій половині четвертої хвилини виконання фізичного навантаження - 60-99 уд./хв. 
За динамікою показників ЧСС упродовж перших 4 хв після відпочинку виявлено, що в середньому індекс гарвардського степ-тесту для I групи становить 56,62, що відповідає слабкому рівню за шкалою оцінювання, для II групи - 68,61, що відповідає середньому рівню. Для III групи цей показник за шкалою оцінювання відповідає доброму стану серцево-судинної системи при виконанні степ-тесту - 83,50 (табл. 1, рис. 1). У жінок-курців простежено низький рівень фізичної працездатності, на відміну від контрольної групи. Це свідчить про функції серцево-судинної системи, порушення діяльності серця як у стані спокою, так і після навантаження, підвищення частоти серцевих скорочень (ЧСС), зниження кровообігу.

Таблиия 1

Показник фізичної працездатності за індексом гарвардського степ-тесту (ІГCT) у досліджуваних осіб $(n=120)$

\begin{tabular}{|c|c|c|c|c|c|c|c|c|}
\hline Показник & Среднє & $\begin{array}{c}\text { Середнс } \\
\text { квадратичне }\end{array}$ & $\begin{array}{c}\text { Похибка } \\
\text { середнього }\end{array}$ & Мінімум & Максимум & $\begin{array}{c}\text { Лiв. } \\
\text { (95\% } \\
\text { ДІ) }\end{array}$ & $\begin{array}{c}\text { Прав. } \\
\text { (95 \% } \\
\text { ДI) }\end{array}$ & $\begin{array}{l}\text { Оцінка } \\
\text { ІГСТ }\end{array}$ \\
\hline $\begin{array}{c}\text { IГCT } \\
\text { I група }\end{array}$ & 56,6 & 7,45 & 1,18 & 41,7 & 82 & 54,2 & 59 & $\begin{array}{r}\text { Слабко } \\
55-64,9 \\
\end{array}$ \\
\hline $\begin{array}{c}\text { IГСТ } \\
\text { II група }\end{array}$ & 68,6 & 8,79 & 1,39 & 52,3 & 87,9 & 65,8 & 71,4 & $\begin{array}{l}\text { Середнє } \\
65-79,9 \\
\end{array}$ \\
\hline $\begin{array}{c}\text { IГСТ } \\
\text { III група } \\
\end{array}$ & 83,5 & 9,23 & 1,46 & 59,8 & 102,7 & 80,5 & 86,4 & $\begin{array}{c}\text { Добре } \\
80-89,9\end{array}$ \\
\hline
\end{tabular}

Примітка. ІГСТ - фізична працездатність, або індекс гарвардського степ-тесту.

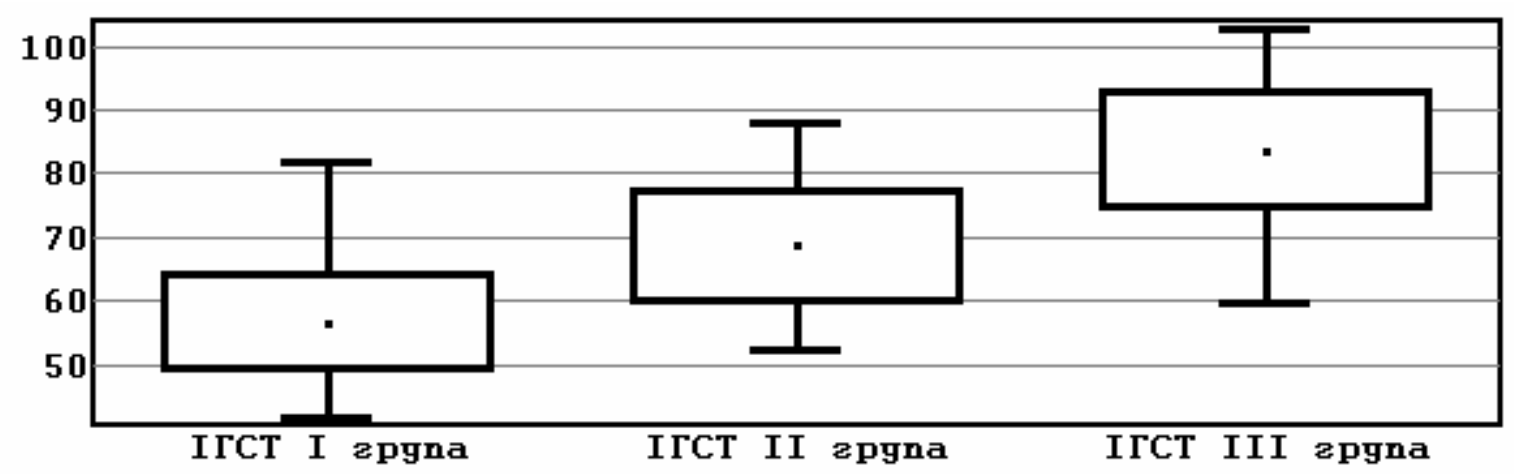

Рис. 1. Фізична працездатність за індексом гарвардського степ-тесту в досліджуваних осіб (IГСТ)

Високий рівень фізичної працездатності забезпечує не лише морфологічну й функціональну перебудову органів системи організму, але й удосконалює процеси регулювання фізіологічних функцій [8], а після викурювання навіть кількох сигарет у день відбувається пригнічення фізичної працездатності.

Аналізуючи повсякденну діяльність молоді, В. Дубровський [6] відзначає невпорядкованість ії організації й хаотичність змісту. Це супроводжується несвоєчасним прийомом їжі, систематичним недосипанням, малим перебуванням на свіжому повітрі, недостатньою руховою активністю, відсутністю гартування, порушенням добового стереотипу через виконання завдання в нічний час, роботою в умовах поганого штучного освітлення, прийомом їжі й уживання тонізуючих напоїв у період, призначений для нічного відпочинку, курінням тощо. Постійно накопичуючись, негативні наслідки такої організації життєдіяльності зазвичай призводить до збільшення кількості хворого підростаючого покоління.

За даними коректурного тесту (кілець Ландольта), у I групі досліджуваних показник розумової працездатності (Р) в середньому дорівнює 481, у II - 621, а для III групи жінок -770 (табл. 2, рис. 2).

Дослідження рівня концентрації уваги за методикою коректурних проб (кілець Ландольта) засвідчило, що в жінок I та II груп показник Р відповідає низькому рівню за шкалою оцінювання, для III групи - задовільному рівню концентрації уваги (табл. 2, рис. 2). 
Це свідчить про те, що тривале куріння згубно діє на нервову систему. Змінюється вища нервова діяльність кори головного мозку, утруднюється проведення збудження вегетативною нервовою системою, у тому числі внаслідок порушення виділення наднирковими залозами адреналіну в курців, поступово знижуються увага, пам'ять, працездатність, ефективність засвоєння нових знань. Тому куріння несумісне з розумовою працею, творчою діяльністю [5].

Таблиия 2

Показник розумової працездатності (Р) за методикою коректурних проб (кілець Ландольта) у досліджуваних осіб $(n=120)$

\begin{tabular}{|c|c|c|c|c|c|c|c|c|}
\hline Показник & Среднє & $\begin{array}{c}\text { Середнє } \\
\text { квадратичне }\end{array}$ & $\begin{array}{c}\text { Похибка } \\
\text { середнього }\end{array}$ & Мінімум & Максимум & $\begin{array}{c}\text { Лів. } \\
\mathbf{9 5} \% \\
\text { ДI) }\end{array}$ & $\begin{array}{c}\text { Прав. } \\
\mathbf{9 5 \%} \\
\text { ДI) }\end{array}$ & Оцінка \\
\hline $\begin{array}{c}\text { Р } \\
\text { І група }\end{array}$ & 481 & 106 & 16,7 & 315 & 657 & 447 & 515 & $\begin{array}{c}\text { Низька } \\
>700\end{array}$ \\
\hline $\begin{array}{c}\text { Р } \\
\text { ІІ група }\end{array}$ & 621 & 83 & 13,1 & 354 & 783 & 594 & 647 & $\begin{array}{c}\text { Низька } \\
>700\end{array}$ \\
\hline $\begin{array}{c}\text { Р } \\
\text { ІІІ група }\end{array}$ & 770 & 74,7 & 11,8 & 660 & 952 & 746 & 794 & $\begin{array}{c}\text { 3адовільно } \\
700-800\end{array}$ \\
\hline
\end{tabular}

Примітка. Р - фізична працездатність, або індекс гарвардського степ-тесту.

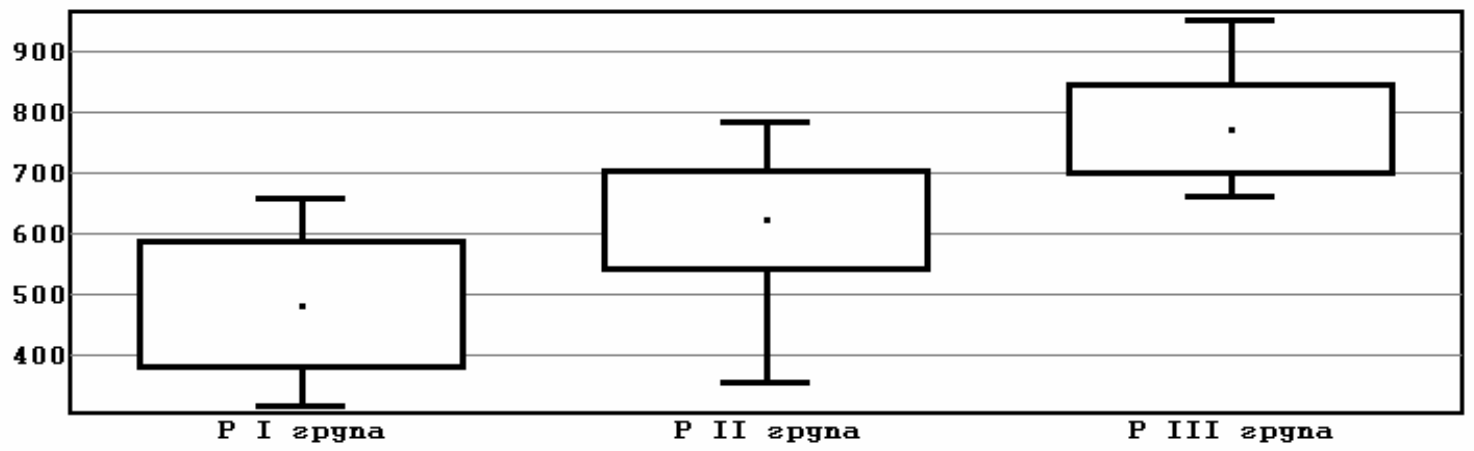

Рис. 2. Розумова працездатність (Р) за методикою коректурних проб (кілещь Ландольта) в досліджуваних осіб

Розумова працездатність невіддільна від загального стану здоров'я й рухової активності. У віці 17-20 років, коли завершується формування організму, його вегетативних функцій, найбільш результатна дія фізичних вправ. У 20-29 років досягає свого найвищого рівня одне з найважливіших для діяльності людини якостей - витривалість. У «студентському» віці відбуваються найбільш активний розвиток і відносна стабілізація психофізіологічних функцій, завершується основний цикл соматичного формування людини, відбувається становлення інтелекту, його цілісності та структури, що організується мисленням. Навчання, що супроводжується постійною розумовою роботою, визначає високий загальний тонус інтелекту [3]. У цей період фізичне виховання стає найважливішим засобом загартування організму й біологічною основою для ефективного процесу пізнавальної діяльності; тренована мускулатура допомагає нервовій системі справлятися з розумовими навантаженнями [3].

Висновки та перспективи подальших досліджень. Установлено, що в жінок-курців рівень фізичної працездатності після визначення індексу гарвардського степ-тесту відповідає слабкому (I група) та середньому (II група), що вказує на низький рівень функціонального стану серцевосудинної системи обстежуваних. Це свідчить, що тютюнопаління негативно впливає на функціонування серцево-судинної системи, порушення діяльності серця як у стані спокою, так і після фізичного навантаження, підвищення частоти серцевих скорочень (ЧСС) та артеріального тиску, а їхні значення залежать від кількості викурених сигарет.

Вивчення рівня концентрації уваги за методикою коректурних проб (кілець Ландольта) показало, що в жінок-курців I й II груп показник розумової працездатності відповідає низькому рівню за шкалою оцінювання. Це можна пояснити тим, що тривале куріння згубно діє на нервову систему, поступово знижуються увага, пам'ять, працездатність, ефективність засвоєння нових знань. 


\section{Джерела та література}

1. Апанасенко Г. Л. Медицинская валеологія : [избр. лекции] / Г. Л. Апанасенко, Л. А. Попова. - Киев : Здоровья, 1998. - 248 с.

2. Брейкина О. А. Физическая активность как один из компонентов здорового образа жизни студентов / О. А. Брейкина // Физическая культура, спорт и здоровье: интеграция теории и практики : материалы междунар. наукч.-практ. конф., посвященной. 60-летию фак. ФКиБЖ ВГПУ, 23-27 октября 2008 г. / ВГПУ. - Воронеж, 2008. - С. 15-17.

3. Виленский М. Я. Фізическая культура в научной организации процесса обучения в высшей школе : учеб. пособие / М. Я. Виленский. - М. : МГПИ, 1982. - 156 с.

4. Виленский М. Я. Физическая культура студента / М. Я. Виленский. - М. : Гардарики, 2001. - С. 68-69, 189.

5. Грачова Т. І. Медико-соціальні проблеми, значення та засоби профілактики шкідливих звичок і наркоманій : метод. розробка для організації самостійної роботи студ. / Т. І. Грачова. - Чернівці, 2006. - 3 с.

6. Дубровский В. И. Спортивная медицина : учеб. для студ. вузов / В. И. Дубровский. - М. : ВЛАДОС, 2005. $-543 \mathrm{c}$.

7. Комаров Ю. М. Все ли вы знаете о курении? / Ю. М. Комаров, О. С. Радбиль. - Киев : Здоровья, 1989. $61 \mathrm{c}$.

8. Летунов С. П. Определение состояния тренированности спортсменов / С. П. Летунов // «Проблемы спортивной медицины. - М. : [б. и.], 1972.

9. Лотоненко А. В. Физическая культура и здоровье : монографія / А. В. Лотоненко, Г. Р. Гостев, С. Р. Гостева, О. А. Григорьев. - М. : Еврошкола, 2008. - 450 с.

10.Лях Ю. Е. Математическое моделирование при решении задач класификации в биомедицине / Ю. Е. Лях, В. Г. Гурьянов // Укр. журн. телемедицини та мед. телематики. - 2012. - Т. 10, № 2. - С. 69-76.

11. Митяева А. М. Здоровый образ жизни : учеб. пособие для студ. вузов / А. М. Митяева. - М. : Академия, 2008. - 144 с.

12. Смирнова І. П. Рекомендації з профілактики і лікування тютюнопаління / І. П. Смирнова, О. О. Кваша, І. М. Горбась, Н. В. Давиденко. - К. : [б. в.], 2006. - С. 13-14 с.

13. Матеріали 1. Якість життя. 31 травня всесвітній день боротьби з курінням [Електронний ресурс]. Режим доступу : http://alnews.com.ua/qualityoflife/10527-31-travnya-vsesvitnijj-den-borotbi-z-kurinnyam.

Апончук Людмила, Шевчук Татьяна, Бернацкая Нина. Анализ показателей умственной и физической работоспособности у курящих женщин. Проанализированы и изучены особенности состояния показателей умственной и физической работоспособности у курящих женщин. Установлено, что у курящих женщин уровень физической работоспособности после определения индекса гарвардского степ-теста соответствует слабому (I группа) и среднему (II группа), что указывает на низкий уровень функционального состояния сердечно-сосудистой системы исследуемых лиц и негативно влияет на адаптацию к физическим нагрузкам и повышает тонус симпатической нервной системы. Исследование умственной работоспособности показало, что у курящих женщин I и II группы показатель умственной работоспособности соответствует низкому уровню по шкале оценивания. Это можно объяснить тем, что длительное курение губительно действует на нервную систему, постепенно снижаются внимание, память, работоспособность, эффективность усвоения новых знаний и в результате ухудшается умственная деятельность (снижается точность восприятея информации).

Ключевые слова: курение, женщины, физическая работоспособность, умственная работоспособность.

Aponchuk Ludmyla, Shevchuk Tetyana, Bernats'ka Nina. Analysis of Mental and Physical Capacity of Female Smokers. Specific indicators of the state of mental and physical ability of female smokers were studied and analyzed. It was established that according to the Harvard step test, female smokers' physical ability meets low (group 1) and medium (group 2) levels, which indicates a low level of functional state of the cardiovascular system of the examinees and accordingly this affects negatively the adaptation to physical activity and increases the tone of the sympathetic nervous system. Studies of mental capacity showed that among female smokers of group 1 and 2 the indicator of mental capacity corresponds to low-level scale of assessment. This may be explained by the fact that longterm smoking has a detrimental effect on the nervous system; it gradually reduces attention, memory, performance, efficiency and assimilation of new knowledge and as a result deterioration of mental activity (reduced accuracy of perception) is observed.

Key words: smoking, women, physical performance, mental performance.

Стаття надійшла до редколегії 28.11.2015 p. 